Keddie, Nikki (1981) Roots of Revolution: An Interpretive History of Modern Iran.

New Haven, CT: Yale University Press.

Kedourie, Elie (1971) Nationalism in Asia and Africa. London: Weidenfeld and Nicolson.

Lyons, F.S. (1979) Culture and Anarchy in Ireland, 1890-1930. Oxford: Oxford University Press.

Marx, Anthony (2003) Faith in Nation: Exclusionary Origins of Nationalism. Oxford: Oxford University Press.

Mosse, George (1990) Fallen Soldiers. Oxford: Oxford University Press.

Nairn, Tom (1977) The Break-up of Britain: Crisis and Neo-Nationalism. London: Verso.

Peel, John (1989) 'The Cultural Work of Yoruba Ethno-genesis', in Elisabeth Tonkin, Maryon McDonald and Malcolm Chapman (eds) History and Ethnicity, pp. 198-215. London: Routledge.

Smith, Anthony D. (1986) The Ethnic Origins of Nations. Oxford: Blackwell.

Wilton, Andrew and Tim Barringer, eds (2002) American Sublime: Painting in the United States, 1820-1880. London: Tate Publishing.

Winter, Jay (1995) Sites of Memory, Sites of Mourning: The Great War in European Cultural History. Cambridge: Cambridge University Press.

Zimmer, Oliver (2003) A Contested Nation: History, Memory and Nationalism in Switzerland, 1761-1891. Cambridge: Cambridge University Press.

ANTHONY SMITH is Professor of Ethnicity and Nationalism in the Government Department at the London School of Economics. Address: Department of Government, London School of Economics, Houghton Street, London WC2A 2AE, UK. [email: Nations@Ise.ac.uk]

\title{
The 'here and now' of everyday nationhood
}

\author{
JON E. FOX
}

University of Bristol, UK

\section{CYNTHIA MILLER-IDRISS}

New York University, USA

Anthony Smith's brief but pointed reply to our debate article, 'Everyday nationhood', reminds us of what inspired us in the first place in our own scholarly pursuit of nationalism. This time, however, we find ourselves in the crosshairs of Professor Smith's critical focus. In the limited space provided 
to us here by the editors of Ethnicities, we aim to respond to what we see to be his two most central criticisms. First, Smith argues that our work is ahistorical. Second, he faults our research agenda for neglecting the question of the relationship between elite and non-elite versions of nationalism. We take each of these criticisms in turn.

Professor Smith accuses us of playing fast and loose with history in our account of everyday nationhood. Coming from an historian of Smith's stature, this is a difficult criticism to ignore. Our response comes in two parts. First, we acknowledge that the primary focus of our research agenda is not historical. We are, as Smith characterizes us, interested in the 'here and now' of nationhood: the everyday contexts in which nationhood becomes (or is made) meaningful for (or by) ordinary people. In a sense, this is a reflection of the methodological assumptions we bring to the study of everyday nationhood: as both sociologists and ethnographers, we have a professional interest in the 'here and now'. Smith is critical of this narrow focus and elaborates an approach that is more sensitive to the historical origins and development of the nation. We do not view these approaches as incompatible but rather as guided by different concerns. Our primary focus is not on Smith's moment of ethnogenesis (for which his work on the topic remains definitive); rather, we concentrate on the ways in which ethnonational idioms - once in circulation - are enacted and invoked by ordinary people in the routine contexts of their everyday lives. Indeed, we are indebted to scholars such as Smith for demonstrating the precise ways in which such idioms have entered circulation. But the availability of such idioms over the longue durée does not in itself explain when, where or how those idioms actually get manipulated by their end users: ordinary people in the 'here and now' of everyday life. This is what our research agenda seeks to explain.

Second, we challenge Smith's point that history is conspicuously missing from our account - at least on a narrow reading of history. Just because we do not elaborate an exclusively historical approach to the study of everyday nationhood does not make our work ahistorical. Indeed, the more general temporal dimensions of nationhood referred to by Smith constitute a cornerstone of our research agenda. To be sure, our 'when' question is not explicitly measured in centuries (though see the first half of Fox's (2006) book with Brubaker et al. (2006) on the history of east central Europe). But neither does it necessarily exclude such a timeframe. Rather, we propose a context-sensitive approach to the study of nationhood where context is understood in multiple temporal and spatial dimensions. Such an approach neither rejects nor insists upon an exploration of the meanings of the nation accumulated over the centuries. We acknowledge that today's quotidian instantiations of nationhood are encrusted with multiple layers of meaning accumulated through the years. But we don't simply assume the contemporary salience of these historical meanings; rather, we try to specify them 
empirically. Miller-Idriss's research on nationhood and citizenship in Germany (forthcoming) searches not for the origins of Germanness in past millennia, but for its more contemporary reworkings in recent generations. Indeed, her aim is to explain how German nationhood and citizenship are the collaborative accomplishment of successive generations of ordinary Germans. In the study of everyday nationhood, time has many dimensions. We suggest a variable salience to nationhood. We should consider not just its historical developmental dimensions, but also its micro-interactional moments, its institutionally embedded and repetitive routines, and the fixed intervals and fleeting effervescences of holiday commemorations and sporting competitions, to name but a few. In each case, the multiple and overlapping temporal contexts of nationhood's everyday salience should be empirically specified rather than surmised from their historically rooted genealogies. ${ }^{1}$

Professor Smith's second main criticism is that our research agenda fails to problematize the relationship between 'elite' and 'non-elite' understandings and uses of nationhood. To this charge we plead guilty. Our goal in the present article has been more modest: to draw attention to the paucity of research in the field of nationalism on the non-elite side of the equation. Exploring the complex relationship between elites and non-elites (to the extent discrete categories of each can be identified and maintained in the first place) is a more ambitious undertaking than we recommend in the present study (although again see Miller-Idriss' work (forthcoming) on the ways in which teachers and students mutually constitute the meanings of nationhood in classrooms in Germany). We instead propose, following Hobsbawm, that more (and more serious) attention be paid to the non-elite side of the equation (Hobsbawm, 1991: 10). ${ }^{2}$ Only when this bias is corrected can we hope to gain a greater appreciation of the relationship between elites and non-elites.

Ultimately what distinguishes Smith's approach from our own is that each is guided by different research questions. Professor Smith wants to know how nations were forged by both elites and non-elites. Indeed, his elaboration of this approach in his reply is not just a call to scholarly arms; it is simultaneously a description of much of the excellent work that he and his like-minded colleagues have already undertaken. Our interest, in contrast, is in examining how nations, once forged, are evoked in everyday life by ordinary people. This does not entail a rejection of the claims of these more historical approaches. Rather, we wish to build on these findings while simultaneously refocusing attention on the everyday meaning and salience of the nation in the world today. This is a question that Smith neither answers nor asks. But the historical emergence and development of the nation does not in itself explain its everyday invocations in the world today. We hope that we have been able to develop a research agenda that sheds some light on this latter and no-less important question. 


\section{Notes}

1 We respond similarly to Smith's contention that our state-centric definition of nationalism is inherently (if unintentionally) ethnocentric. We concede that our definition does somewhat narrowly link the nation to the state (and thereby carry a Eurocentric bias). But our definition of nationhood in everyday life does not. Indeed, we submit that it is Smith who assumes such a linkage between the political and the national in the realm of the everyday. For us, this is again an empirical question: how, if at all, ethnicity and nationhood are politically inflected in everyday talk and interaction. Such questions must be asked not only in the west, but in the east, north, and south as well.

2 Smith, too, is sympathetic to increased attention to the role of non-elites. But his primary interest in the public performance of national rituals still privileges this preferred domain of elites. While national commemorations are indeed important venues for non-elite participation (see Fox, 2006), they are not the only such venues. The danger of focusing immediately on the linkages between elites and non-elites is that such investigations often take elite sites of nationalism as their starting point. We, in contrast, propose beginning our investigation of nationhood 'from below' before looking for the linkages with elite brands of nationalism.

\section{References}

Brubaker, Rogers, Margit Feischmidt, Jon Fox and Liana Grancea (2006) Nationalist Politics and Everyday Ethnicity in a Transylvanian Town. Princeton, NJ: Princeton University Press.

Fox, Jon E. (2006) 'Consuming the Nation: Holidays, Sports, and the Production of Collective Belonging', Ethnic and Racial Studies 29(2): 217-36.

Hobsbawm, Eric J. (1991) Nations and Nationalism since 1780: Programme, Myth, Reality. Cambridge: Cambridge University Press.

Miller-Idriss, Cynthia (forthcoming) Blood and Culture: Race, Citizenship, and National Belonging in a Re-Imagined Germany. Durham, NC: Duke University Press. 